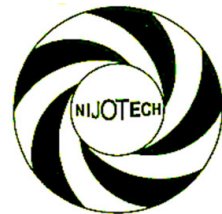

Nigerian Journal of Technology (NIJOTECH)

Vol. 35, No. 1, January 2016, pp. 91 - 96

Copyright@ Faculty of Engineering, University of Nigeria, Nsukka,

Print ISSN: 0331-8443, Electronic ISSN: 2467-8821

www.nijotech.com

http://dx.doi.org/10.4314/njt.v35i1.15

\title{
SUBSTRATE REDUCTION KINETICS AND PERFORMANCE EVALUATION OF FLUIDIZED-BED REACTOR FOR TREATMENT OF BREWERY WASTEWATER
}

\author{
C. S. Okoli ${ }^{1, *}$ and P. C. Okonkwo² \\ 1 Department of Chemical EngineERing, UniVERSity of Uyo, Uyo. AKWA IBOM STATE. NIGERIA. \\ 2 Department of Chemical Engineering, Ahmadu Bello University, Zaria. Kaduna State. NIGERIA \\ Email addresses.1 chrisoko81@yahoo.com, ${ }^{2}$ chemstprom@yahoo.com
}

\begin{abstract}
$A$ pilot scale anaerobic fluidized-bed reactor was operated for treating brewery wastewater at nine different hydraulic retention time (HRTs) of 2, 3, 4, 5, 6, 7, 8, 9, and 10hr. The COD reduction efficiencies increased from 9.8\% to 74.1\% with increasing HRT from 2 to 10hr.Similarly, the corresponding BOD 5 reduction efficiencies increased from $38.0 \%$ to $92.9 \%$ with the same increase in HRT. The predicted effluent substrate concentration values of Modified Stover-Kincannon model were found to be in strong agreement with the experimental values. This is due to proper solubilization and consumption of entrapped substrates in the fluidized-bed reactor since the microbial cells have maximum opportunity to interact with the entrapped substrates in the reactor. The kinetic parameters were determined using existing linear models with experimental data. Modified Stover-Kincannon model showed high correlation coefficient $\left(R^{2}=0.9996\right)$ only in predicted effluent concentration of wastewater. This shows that this model can be best used to predict effluent COD concentration in a fluidized bed reactor treating brewery wastewater. Similarly, FIRST ORDER MODEL has the highest correlation coefficient in the plot using experimental data. This means that first order model can be used to represent the real biological degradation that takes place during the treatment of waste water by microorganisms in a fluidized-bed reactor system treating brewery wastewater. This model and kinetic parameters obtained in this work can be employed in the design of industrial size- fluidized bed reactor for treatment of brewery waste water. Maximum utilization rate constant $\left(U_{\text {max }}\right)$ determined is $11.75 \mathrm{~g}$ COD/l.hr and the saturation value constant $\left(K_{B}\right) 131.41 \mathrm{~g}$ COD/l.hr was also determined. The values of kinetic constants were also used to predict the effluent COD concentration. It was observed that the simulated data (predicted data) were in good harmony with the experimental data counterpart in modified Stover -Kicannon model, The strength of the above-mentioned model can be observed from the correlation coefficient obtained from the model as $R^{2}=0.9996$ in modified Stover-kicannon model.
\end{abstract}

Keywords. Anaerobic decomposition: Brewery wastewater; Fluidized-bed reactor; Kinetic models.

\section{INTRODUCTION}

Brewing industry holds a strategic economic position in the food industry with the annual world beer production exceeding 134 billion liters in 2002 [1]. Beer is the fifth most consumed beverage in the world behind tea, carbonates, milk and coffee and it continued to be a popular drink with an average consumption of 23 liters per person per year [17]. In a typical brewing process, an estimate of 1113 liters of fresh water is required to produce just 159 liters of beer. That is to say, about $65 \%$ of the total water used in the brewery process ends up as wastewater while a small portion of the water is boiled-off during the fermentation vessel boil or captured in the spent grain [1].

Waste water from a large scale brewing industry located at Kudenda Industrial Area, Kaduna State, Nigeria was employed in the study. The Brewing industry utilizes water, malted barley, sorghum, brewer yeast and hops for its daily production of beer thereby generating wastewater characterized with high COD and $\mathrm{BOD}_{5}$ at the average concentration of $7137.67 \mathrm{mg} \mathrm{COD} / \mathrm{l}$ and $2177.85 \mathrm{mg} \mathrm{BOD} / \mathrm{l}$ respectively as at October 2009 through fermentation vessel, keg washes, bottling as well as other wash water in the brewery. Considering energy costs and environmental protection, discharging of brewery wastewater to the environment has attracted researchers and public attention on anaerobic treatment of industrial wastewater in particular to those from brewery industry.

Complex group of organic solid (carbohydrate, protein, fat) containing Carbon $(\mathrm{C})$, Nitrogen $(\mathrm{N})$, Oxygen $(\mathrm{O})$, Hydrogen $(\mathrm{H})$, Phosphorous(P), are commonly found present in the typical brewery wastewater. Direct discharge of such wastewater to the water body without reducing its organic content to the minimum acceptable level causes death of aquatic 
lives, pollute the river in question thereby making it unacceptable to be used by the general public. A wide variety of industrial wastewater, brewery wastewater [4], and piggery wastewater [5] were suggested to have been treated using up-flow anaerobic sludge blanket (UASB) but long period of time is needed to develop good bacterial floc for successful operation of UASB reactor system before the treatment begins [6]. Open pit (aerobic) treatment system which is currently being employed at the brewery is characterized by high sludge generation with its attendant disposal problems. Slaughterhouse wastewater [7] and corn starch wastewater [8] have been treated using Fluidized-bed reactor system. However, not many studies have been done on anaerobic fluidized-bed reactor system as alternative/remedy to the short comings of UASB and open pit system. High rate anaerobic fluidized-bed treatment systems can be used to treat varieties of industrial wastewater since it produces less sludge; has lower energy requirements and produces methane which may be burnt as an additional energy source[9]. In this study, anaerobic fluidized-bed reactor treatment was chosen to treat the brewery effluent wastewater. Anaerobic fluidized-bed reactors are currently utilized to achieve several biological wastewater treatment goals. The biological waste water treatment is one of the effective methods in reducing/ eliminating the organic matter present in brewery wastewater. The important issues of energy consideration and environmental protection have serious interests on anaerobic treatment of industrial wastewater in particular to those from brewery industry [10].

The performance of bacteria in degrading the organic matter can be described by kinetics. Moreover, it is an important tool to understand the anaerobic degradation, reactor design and operation [12].Generally, kinetic analysis can be employed as a route for describing and predicting the performance of any biological treatment system [11]. Apart from many kinetic models available in literature, three different models such as Grau second order, modified Stover-Kin cannon model and first order kinetic models were applied to determine the kinetics parameters of fluidized-bed reactor using brewery wastewater and verify the validity of the models by comparing the experimental effluent COD and predicted COD concentration at increasing hydraulic retention time (HRT).

\section{MATERIALS AND METHODS}

\subsection{Instrumentation and Equipment}

The anaerobic fluidized-bed reactor consists of frustum - like shaped glass material column with a total working volume of 2 litres. The reactor column has total height of $1.45 \mathrm{~m}$ with a progressive increase in internal diameter from $42 \mathrm{~mm}$ at the bottom to 60 $\mathrm{mm}$ at the top. The effluent recycle port was located at
$550 \mathrm{~mm}$ from the top with the diameter of $22 \mathrm{~mm}$. Below the effluent recycle port, is a solid trapper made of fine diffusible filter cloth located inside the reactor, about $290 \mathrm{~mm}$ from the bottom of the reactor. This enclosure prevents excessive

washout of solids and it maintains good bacterial floccs and conducive environment for better degradation of organic matter in the reactor. Twenty gram activated carbons of size range (75-300) $\mu \mathrm{m}$ were used to serve as support material for microbial concentration in the reactor. About $12 \mathrm{l}$ capacity laboratory tanks were used as effluent collection tank and feed tank respectively. The feed tank was mounted on hot iron plate which is thermostatically controlled to maintain the range of temperature $\left(34^{\circ} \mathrm{C}-38^{\circ} \mathrm{C}\right)$ which was needed for the work (mesophilic temperature). The upper section of the reactor contains a conical-shaped gas-liquid separator to allow the biogas produced to vent-off into a carbon (IV) oxide absorption unit. The carbon (IV) oxide is absorbed by bubbling the gas through a $2 \mathrm{M}$ solution of calcium hydroxide solution placed in $500 \mathrm{ml}$ flat bottom flask. The biogas rich in methane is collected through downward displacement of water). Sample ports were located along the reactor length through which reactor contents were collected for analysis .The reactor length was lagged to minimize heat loss of the content to the environment .The pump discharge was located very close to the reactor feed entrance point to minimize head loss[10].

\subsection{Experimental Procedure}

The reactor was initially filled with $20 \mathrm{~g}$ activated carbon $(75-300 \mu \mathrm{m})$, and then the 168hrincubated seed sludge $(100 \mathrm{ml})$ was added .The anaerobic seed used in this work was collected from lagoon process system treating brewery wastewater. Brewery wastewater obtained from the brewing industry located at Kudenda Industrial Area, Kaduna, Kaduna State, Nigeria, was charged raw into the feed tank. The study employed a fluidized-bed digester, with liquid volumetric flow rate of $1.7 \times 10-6 \mathrm{~m}^{3} / \mathrm{s}$ and superficial velocity of $0.0012 \mathrm{~m} / \mathrm{s}$.. The pressure drop across the fluidized-bed was calculated to be $1.848 \mathrm{~N} / \mathrm{m}^{2}$.

The reactor length was lagged to prevent heat loss to the surrounding. The $\mathrm{pH}$ was adjusted to neutral point, and then the reactor was operated by pumping the feed from the feed tank into the reactor, continuously at volumetric flow of $6.28 \mathrm{l} / \mathrm{h}$ in all the experiment, the biogas produced was passed through a separator where carbon (iv) oxide was absorbed in a $2 \mathrm{M}$ solution of $\mathrm{Ca}(\mathrm{OH})_{2}$ and the biogas rich in methane gas was collected over water in a well graduated measuring cylinder by downward displacement of water. IM sodium hydroxide solution was added periodically to maintain the $\mathrm{pH}$ range of 6.8 to 7.2 in the reactor. In each run, the same concentration of the feed was used at a particular hydraulic retention time (HRT). This continued for different HRT at the same

Vol. 35, No. 1, January 2016

92 
initial feed concentrations and feed flow rate. The samples analysis were taken periodically and Lagrange interpolation technique was applied to the experimental data to bridge the gap between the period of system shut-down and the continuous process. All the chemical analyses of the parameters (chemical oxygen demand (COD), biochemical oxygen demand $\left(\mathrm{BOD}_{5}\right)$, suspended solids (SS), dissolved solids

(DS), total solids (TS), alkalinity, volatile fatty acid, nitrate, phosphorous and oil \& grease) were done according to the standard Methods [14].

\section{RESULTS AND DISCUSSIONS}

The raw brewery wastewater was collected from local brewery industry and was analyzed as per standard method [14] and features and compositions of this wastewater are summarized in Table 1.

During the continuous treatment process, the effluent wastewater was collected and analyzed according to standard method. Data obtained during continuous operation for effluent parameter analysis is shown in Table 2 .

\subsection{Substrate Removal Kinetics Models}

The behavior of every anaerobic reactor can be visualized through the kinetic study of its design. Generally, the result of kinetic studies obtained from the present study can be used to estimate treatment efficiency of full-scaled reactor with the same operational conditions. In fluidized-bed reactor treating brewery wastewater, the media for bacteria attachment are kept in suspension by drag force exerted by up-flowing wastewater, thus, providing opportunity for maximum consumption of substrate in the reactor. By employing various kinetic models, such as modified Stover-Kincannon, Grau second order and first order, the kinetics parameters can be estimated.

\subsubsection{Grau Second-Order Model}

In fluidized-bed reactor treating wastewater, the steady state general equation of the Grau second order kinetic model with simplified assumption is represented in the equation 1 to estimate dimensions less grau second order constants ( $a$ and $b$ ).

Table 1: Summary of Characterization Results of Raw Sample

\begin{tabular}{lc}
\hline Parameter & Value \\
\hline $\begin{array}{l}\text { Chemical oxygen demand( COD) } \\
\text { (g/l) }\end{array}$ & 7.13 \\
$\begin{array}{l}\text { Biological oxygen demand } \\
\text { (BOD } 5 \text { ) (g/l) }\end{array}$ & 2.18 \\
Total solid(TS) (g/l) & 4.08 \\
Dissolved solid (DS) (g/l) & 2.97 \\
Suspended solid (SS) (g/l) & 1.11 \\
Phosphorous (g/l) & 0.051 \\
Nitrate (g/l) & 0.059 \\
pH & 5.17 \\
Oil and Grease (g/l) & 0.00000008 \\
Organic loading (QSo/V) & $22.38 g C O D / l / h$ \\
\hline
\end{tabular}

The predicted effluent concentration $\left(\mathrm{S}_{\mathrm{G}}\right)$ can be evaluated from equations 2 [16].

$$
\begin{aligned}
& \frac{S o \theta_{H}}{S o-S e}=b \theta_{H}+a \\
& S c=S_{o} \frac{S o-\theta_{H}}{b \theta_{H}+a}=
\end{aligned}
$$

\begin{tabular}{|c|c|c|c|c|c|c|c|c|c|}
\hline $\operatorname{HRT}\left(\theta_{\mathrm{H}}\right)(\mathrm{h})$ & 2 & 3 & 4 & 5 & 6 & 7 & 8 & 9 & 10 \\
\hline $\operatorname{SRT}\left(\theta_{c}\right)(h)$ & 0.35 & 0.53 & 1.02 & 0.53 & 0.35 & 0.44 & 0.59 & 0.40 & 0.27 \\
\hline $\operatorname{coD}(\mathrm{S})(\mathrm{g} / \mathrm{l})$ & 6.40 & 5.90 & 5.40 & 4.40 & 3.30 & 2.90 & 2.50 & 2.20 & 1.80 \\
\hline $\mathrm{BOD}_{5}(\mathrm{~g} / \mathrm{l})$ & 1.30 & 1.10 & 0.90 & 0.60 & 0.40 & 0.30 & 0.20 & 0.20 & 0.20 \\
\hline $\mathrm{X}(\mathrm{Cfu} / \mathrm{l}) \times 10^{9}$ & 2.05 & 2.13 & 2.20 & 2.24 & 2.28 & 2.36 & 2.44 & 2.54 & 2.23 \\
\hline $\mathrm{X}_{\mathrm{e}}(\mathrm{Cfu} / \mathrm{l}) \times 10^{9}$ & 1.89 & 1.29 & 0.69 & 1.38 & 2.06 & 1.69 & 1.32 & 2.04 & 2.76 \\
\hline $\mathrm{ALK}\left(\mathrm{mgCaCO}_{3} / \mathrm{l}\right)$ & 99.36 & 533.33 & 967.32 & 1038.66 & 1110.00 & 1126.30 & 1142.59 & 1153.00 & 1163.40 \\
\hline VFA(mgaceticacid/l) & 342.44 & 486.22 & 630.00 & 581.06 & 533.91 & 548.59 & 563.26 & 579.02 & 594.78 \\
\hline $1 / \mathrm{S} \times 10^{-4}$ & 1.6 & 1.7 & 1.8 & 2.3 & 3.0 & 3.4 & 4.0 & 4.6 & 5.4 \\
\hline $\mathrm{E}_{\mathrm{COD}}(\%)$ & 9.8 & 16.8 & 23.8 & 38.7 & 53.6 & 59.3 & 64.9 & 69.5 & 74.1 \\
\hline$\left(\mathrm{S}_{0}-\mathrm{S}_{\mathrm{e}}\right) / \theta_{\mathrm{H}} \mathrm{X} \quad \times 10^{-7}$ & 1.70 & 1.87 & 1.92 & 2.46 & 2.74 & 2.56 & 2.37 & 2.17 & 2.28 \\
\hline $1 / \theta_{\mathrm{c}}$ & 2.86 & 1.89 & 0.98 & 1.89 & 2.85 & 2.27 & 1.69 & 2.50 & 3.70 \\
\hline $\mathrm{L}_{\mathrm{org}}=\mathrm{QSo} / \mathrm{V}$ & 20.10 & 18.53 & 16.96 & 13.82 & 10.36 & 9.11 & 7.85 & 6.91 & 5.65 \\
\hline$\theta_{\mathrm{H}} \mathrm{So} /(\mathrm{So}-\mathrm{S})$ & 20.41 & 17.86 & 16.81 & 12.92 & 11.19 & 11.80 & 12.33 & 12.95 & 13.50 \\
\hline$V / Q\left(S_{0}-S_{e}\right)$ & 0.22 & 0.38 & 0.54 & 0.86 & 1.22 & 1.34 & 1.47 & 1.57 & 1.70 \\
\hline $\mathrm{V} / \mathrm{QS}_{\mathrm{o}}$ & 0.05 & 0.05 & 0.06 & 0.07 & 0.10 & 0.11 & 0.13 & 0.15 & 0.18 \\
\hline $\ln \mathrm{S} / \mathrm{So}$ & 0.11 & 0.19 & 0.28 & 0.48 & 0.77 & 0.90 & 1.05 & 1.18 & 1.38 \\
\hline $\mathrm{S}_{\mathrm{G}} \quad(\mathrm{g} \mathrm{g} / \mathrm{D} / \mathrm{l})$ & 6.00 & 5.50 & 5.10 & 4.10 & 3.10 & 2.70 & 2.30 & 2.10 & 1.70 \\
\hline $\mathrm{S}_{\mathrm{MS}}(\mathrm{gCOD} / \mathrm{l})$ & 5.90 & 5.40 & 5.00 & 4.00 & 3.00 & 2.70 & 2.30 & 2.00 & 1.60 \\
\hline $\mathrm{S}_{\mathrm{F}(\mathrm{gCOD} / \mathrm{I})}$ & 5.30 & 4.50 & 3.80 & 2.90 & 2.00 & 1.70 & 1.40 & 1.10 & 0.90 \\
\hline
\end{tabular}

Table 2 : Summary of Operational Parameter Values and Steady State results. 


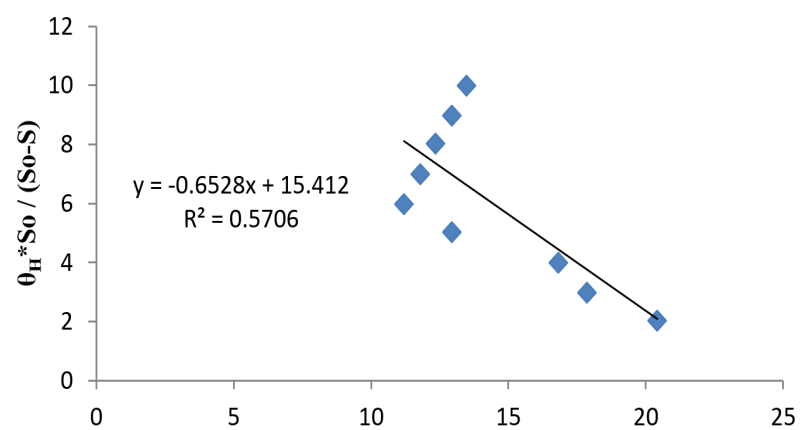

Figure 1: Determination of Kinetic Constants for Grau Second-Order Model

In order to determine the Grau second-order $b$, equation (1) can be plotted (as shown in Figure. 1). $\mathrm{S}_{\mathrm{G}}$ is the predicted effluent substrate concentration using Grau second model. $\mathrm{a}$ and $\mathrm{b}$ are constants.

From Figure 1, the value of the correlation coefficient is low. The reason can be possibly due to the high fluctuating effluent cells (Xe) washed-out of the reactor by the up-flow wastewater from the bottom of the reactor with decreasing organic loading rate $\left(\mathrm{L}_{\mathrm{org}}\right)$ (see Table 2).Here, only the solubilized substrates are made available for consumption by the remaining cells in the reactor $(\mathrm{X})$,resulting in small amount of COD removal, thus, effluent COD decreased insignificantly. The kinetic parameters, $a$ and $b$, can be calculated from the intercept and slope of the straight line, respectively. Calculated values of $a$ and $b$ were found to be 0.6528 and 15.412 , with a correlation coefficient (0.5706). The average initial concentration of substrate in the fluidized-bed reactor was $7.13 \mathrm{~g} / \mathrm{L}$, the second-order substrate removal rate constants can be obtained from value a (0.6528). Estimated values of $a$ and $b$ can be used to predicting effluent concentrations see equation (2) above and compared with the literature values, see Table 3.

\subsubsection{Modified Stover-Kincannon Model}

The Stover-Kincannon model, originally proposed for rotating biological contactors (RBCs), assumed that the substrate utilization rate could be expressed as a function of the organic loading rate for biofilm reactors. The contribution of the suspended biomass to substrate removal was assumed to be negligible in comparison to the attached biomass on the support media. Therefore, the disc surface area of the rotating biological contactor was used to represent the total attached-growth active biomass concentration in the original model. However, the suspended microorganisms within the media interstitial void spaces between the packing and bio-growth was considered to be a significant factor in substrate removal in anaerobic filters and the effective volume of the reactor can be used instead of the surface area of the support media [15]. Therefore, using the principle of material balance for complete mixed flow fluidized bed reactor type, the maximum utilization

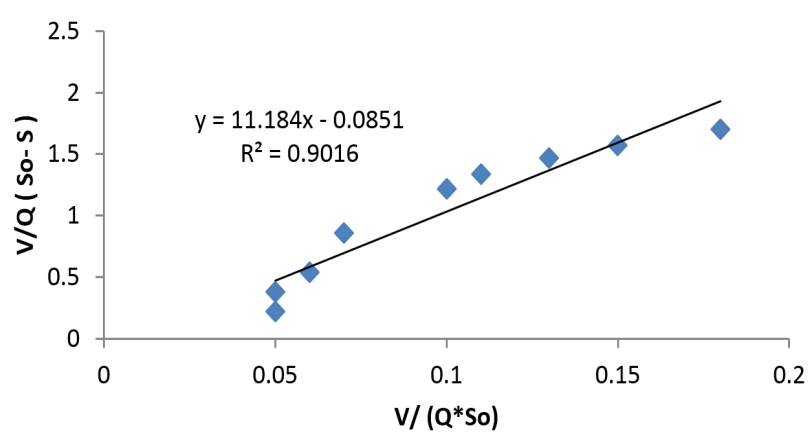

Figure 2: Determination of kinetic constants for modified Stover-Kicannon model

rate constant, the saturation value constant and predicted effluent concentration will be simplified with necessary steady state assumption to arrive at the equation 3 and 4 [19]:

$$
\begin{aligned}
& \frac{V}{Q(S o-S e)}=\frac{K_{B}}{U_{\max }} \frac{V}{Q S o}+\frac{1}{U_{\max }} \\
& S_{M S}=S_{o}-\frac{U_{\max }}{K_{B}+\left(Q S_{o} / V\right)}
\end{aligned}
$$

$\mathrm{U}_{\max }$ is the maximum utilization rate constant (mg/l.h), $\mathrm{K}_{\mathrm{B}}$ is the Saturation value constant showing the amount of substrate consumed per liter of wastewater in an hour inside the reactor $(\mathrm{gCOD} / \mathrm{L} / \mathrm{hr}$, $\mathrm{Q}$ is the volume flow rate $(\mathrm{L} / \mathrm{h})$ of the feed, Here, saturation value constant $\left(\mathrm{K}_{\mathrm{B}}\right)$ and maximum utilization rate constant $\left(\mathrm{U}_{\max }\right)$ can be obtained.

From (3) above, the linear plot of $\frac{V}{S o}$ against $\frac{V}{Q S o}$ gave a linear relation as shown below from where the kinetic constants $\left(\mathrm{K}_{\mathrm{B}}\right.$ and $\left.\mathrm{U}_{\max }\right)$ can be determined through slope and intercept of the plot.

The values of $U_{\max }$ and $K_{\mathrm{B}}$ were obtained from the slope and intercept of Equation 3. According to Figure 2 , the values of $U_{\max }$ and $K_{\mathrm{B}}$ were calculated to be $11.75 \mathrm{~g} \mathrm{COD} / \mathrm{l} / \mathrm{hr}$ and $131.41 \mathrm{~g} \mathrm{COD} / \mathrm{l} \mathrm{h}$ respectively. The values of $U_{\max }$ were significantly high but lower than the maximum organic loading rate (22.38 $\mathrm{g}$ COD $/ \mathrm{l} / \mathrm{h}$ ) applied to the system during the study, indicating that some of the insoluble organic polymers on entering the reactor escaped hydrolysis in the reactor by extra-cellular enzyme produced by hydrolytic bacteria. In this case denying the opportunity for the microorganism in breaking-down the complex organic matter, only the hydrolyzed complex organic polymer is made available for use by acidogenic bacteria of the next stage.

\subsubsection{First Order Model}

In an anaerobic fluidized-bed system treating brewery wastewater, the first order model is applied to study the biodegradation of the waste material in the reactor. Applying material balance to the complete mixed reactor with simplified steady state assumption, the kinetic constant can be evaluated [18].Also effluent substrate concentration can be predicted using equation 5 and 6 . 


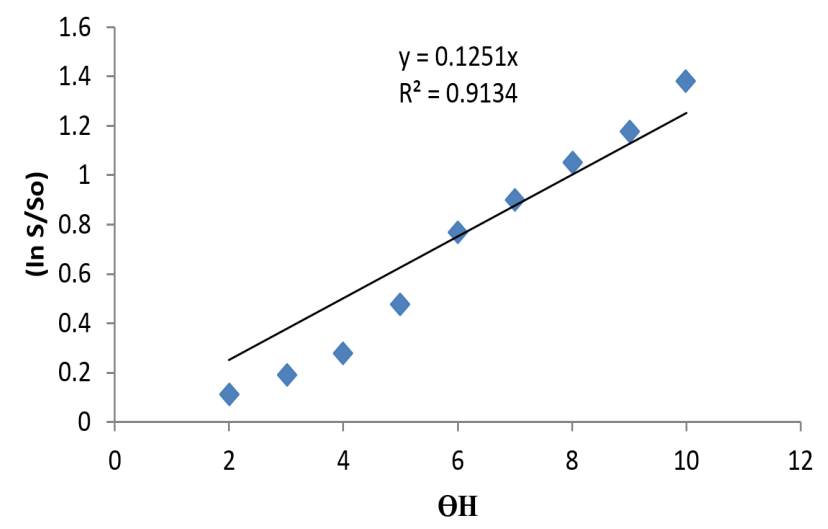

Figure 3: Determination of kinetic constant for first order model

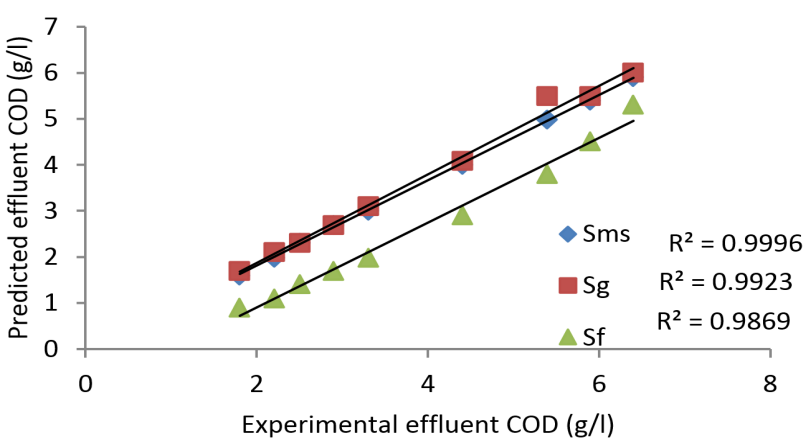

Effluent substrate for Modified Stover-Kicannon Model (SMs) $R^{2}=0.9996$, Grau Second Order Model $(\mathrm{Sg}) \mathrm{R}^{2}=\mathbf{0 . 9 9 2 3}$, First Order Model (Sf) $\mathbf{R}^{2}=\mathbf{0 . 9 8 6 9}$

Figure 4: Comparison of Predicted and Experimental COD Values

Table 3: Comparison of the Kinetic Coefficients

\begin{tabular}{llllll}
\hline Feed waste water \& Reactor Used & $\mathrm{a}(\mathrm{per}$ day) & $\mathrm{b}(\mathrm{per}$ day) & $\mathrm{Umax}(\mathrm{g} / \mathrm{l} / \mathrm{d})$ & $\mathrm{K}_{\mathrm{B}}(\mathrm{g} / \mathrm{l} / \mathrm{d})$ & Reference \\
\hline Brewery wastewater, UAFB & 0.027 & 0.642 & 0.49 & 5.48 & This Study \\
Food processing ,anaerobic Filter & - & - & 22.93 & 23.59 & {$[15]$} \\
Simulated texile, UASB & - & - & 7.5 & 8.20 & {$[15]$} \\
Slaughterhouse, SGBR & 0.017 & 1.05 & 192.30 & 206.60 & {$[15]$} \\
Pharmaceutical, AHR & 0.031 & 1.067 & 108.69 & 115.66 & \\
Formaldehyde,UAFB & 0.640 & 9.36 & 3.40 & 4.60 & {$[11]$} \\
Simulated waste water, UASB & 0.562 & 1.095 & 7.50 & 8.20 & {$[11]$} \\
\hline
\end{tabular}

Source $[11,15]$

$$
\begin{aligned}
& \text { In } \frac{S}{S o}=k \theta \\
& S_{F}=\frac{S_{o}}{\theta_{H} k_{1}+1}
\end{aligned}
$$

Note, the values for the kinetic constants $\left(\mathrm{a}, \mathrm{b}, \mathrm{K}_{\mathrm{B}}\right.$, and Umax) generated in this work as per hour are converted per day for proper comparison with the literature values.

\subsubsection{Prediction of data and Validation of models}

From the present work, in order to test the validity of the models, results obtained from the experimental effluent COD values using fluidized bed reactor system were compared with the predicted values obtained from the existing models (see Figure 4).Here, high correlation values ( $0.9996,0.9923$ and 0.9869$)$ obtained for Modified Kincannon Model, Grau SecondOrder, and First Order Model respectively in such descending order of magnitude show that the predicted data are in strong agreement with the experimental data, but this relationship weakens as in the case Grau Second-Order model when considered the correlation coefficient obtained from linear plot of experimental data generated. But in comparison, from Figures 1, 2, 3 and 4 for the determination of kinetic parameters, the result obtained in terms of correlation coefficient $\left(\mathrm{R}^{2}\right)$ is an indication that Modified StoverKicannon Model represented the experimental and predicted data with $\left(\mathrm{R}^{2}=0.9016\right.$ and $\left.\mathrm{R}^{2}=0.9996\right)$ respectively. Also, first order model has correlation coefficient for experimental and predicted data plot as $\left(R^{2}=0.913\right.$ and $\left.R^{2}=0.9869\right)$ respectively while the Grau second order has the values in experimental and predicted data as $\left(R^{2}=0.5706\right.$ and $\left.R^{2}=0.9923\right)$ respectively. From the values of $\mathrm{R}^{2}$ obtained in the two cases (experimental data and predicted data), one could inferred that MODIFIED STOVER- KICANNON MODEL can be used to predict effluent COD values properly while FIRST ORDER MODEL can be used to represent the real biological degradation that takes place during the treatment of waste water by microorganisms in a fluidized-bed reactor system treating brewery wastewater.

\section{CONCLUSION}

This study showed the effect of variation of hydraulic retention times on the performance evaluation of fluidized-bed reactor system in treating brewery wastewater. By conducting the experiment at ascending order of hydraulic retention time (HRTs) from $2,3,4,5,6,7,8,9,10 \mathrm{hr}$,it was found that the maximum COD and BOD $_{5}$ removal efficiency of 74.1 and 92.9 percent from initial concentration of $7.14 \mathrm{~g}$ $\mathrm{COD} / \mathrm{l}$ and $2.18 \mathrm{gBOD}_{5} / \mathrm{l}$ was recorded at $10 \mathrm{hr} \mathrm{HRT}$. The result showed that the substrate reduction increases as HRT increases. Strong significant correlation was not found between predicted and experimental effluent substrate concentration in Grau second order model. This is as a result of insignificant 
substrate removal efficiency maintained due to decrease in organic loading rate in the reactor as the hydraulic retention time increased. The predicted effluent substrate concentration values of Modified Stover-Kincannon model were found to be in strong agreement with the experimental values (see figure 4).This is due to proper solubilization and consumption of entrapped substrates in the fluidizedbed reactor since the microbial cells have maximum opportunity to interact with the entrapped substrates in the reactor. The kinetic parameters were determined using existing linear models with experimental data. Modified Stover-Kincannon model showed high correlation coefficient $\left(\mathrm{R}^{2}=0.9996\right)$ only in predicted effluent concentration of wastewater. This shows that this model can be best used to predict effluent COD concentration in a fluidized bed reactor treating brewery waste water. Similarly, FIRST ORDER MODEL has the highest correlation coefficient in the plot using experimental data. This means that first order model can be used to represent the real biological degradation that takes place during the treatment of waste water by microorganisms in a fluidized-bed reactor system treating brewery wastewater.(see Figure 3 and Figure 4 respectively).. This model and kinetic parameters obtained in this work can be employed in the design of industrial sizefluidized bed reactor for treatment of brewery waste water.

\section{REFERENCES}

1. Ockert, $\mathrm{K}$ and Porter F, "Brewery Engineering and Plant Operation", Green Press, Vol. ,13, 2001, pp 129158, London,

2. Driessen ,W., and Vereijken, T..."Recent development in biological treatment of brewery effluent". The Institute and Guild of Brewering Convention, Livingstone, Zambia, March2-7,2003.

3. Nyilimbabazi, N., Banadda, N., Nhapi, I., and Wali, U.G,"Characterization of brewery wastewater for reuse in Kigali", Open Environmental Engineering Journal, Vol4,2011, pp. 89-96,Rwanda.

4. Cronin. C and Lo ,K.V, "Anaerobic treatment of brewery wastewater using uasb reactor seeded with activated sludge". Bioresourecs Tech. Vol. 64, pp 33-38, 1998.

5. Sanchez, E., Borja, B., Travieso, L., Martin, A. \& Colmenarejo, M. "Effect of organic loading rate on performance of a secondary upflow anaerobic sludge bed reactor treating piggery waste". Bioresource Technology, Vol. 96, 2005, pp.335-334.

6. Basadorj D, "Anaerobic treatment of brewery wastewater using upflow anaerobic sludge blanket reactors seeded with activated sludge", Strategic Technology, IFOST, 2007 International forum, IEEE. Ilaanbaatar.
7. Sreekirshnan, T. R., Ramachandran. K. B \& Ghosh, P. "Effect of operating variables on biofilm formation and performance of anaerobic fluidized bed reactor". Biotech \& Bio Eng, Vol. 37, 1991, pp435-443.

8. Borja. R, Charles. B and Zhengijian, W., Kinetic Evaluation of Anaerobic Fluidized-Bed Reactor Treating Slaughter House Wastewater, Bio Resource Tech.52, 1991, 63-167

9. McCornick P. G., HijaziA. ,and Sheik B.." Wastewater reuse and reclamation: Progression of Water Reuse Standard in Jordan", International Development Research Centre. Vol., 23, Number 1, 2004.

10. Okonkwo P.C and Okoli C. S.."Treatment of Brewery Wastewater in a Fluidized-bed Digester" $J$.of Chemical and Process Engineering Research, Vol., 13, 2013.

11. Mullai, P., Arulselvi, S., Ngo, H.H and Sabarathianam, P.L. Experiments and ANFIS Modelling for biodegradation of Pencillin-G wastewater Using Anaerobic Hybrid Reactor. Bioresourse Technology, 102, 2011, pp. 271-276.

12. Chen, C., Lin, J. S., and Cheng, J. S. "Kinetics of Hydrogen Production With Continuous Anaerobic Cultures Utilizing Sucrose and Limiting Substrate", Appl, Microbiology Biotechnology. Vol.,57, 2001, PP.56-64

13. Hu, W.C., Thayanithy, K. and Forster, C.F.."Kinetic study of anaerobic digestion of ice-cream waste water", Process Biochem,Vol., 37,2002, pp 965-971.

14. American Public Health Association (APHA), "Standard Methods for the examination of water and wastewater",APHA,AWWA,WPCF,16 $16^{\text {th }} \mathrm{Ed}, 1985$

15. Jin, H. O., Timothy, G. E., Hans, V.L., Sih, W. S, Thomas, L, Raj, R,."Performance evaluation of the pilot-scaled granular bed reactor (sgbr) for industrial wastewater treating septic tank effluent using recycled rubber effluent". Graduate thesis and dissertation,2012, Iowa State University, Ames, Iowa,

16 Grau, P. ,Dohanyas, M and Chudoba, J. "Kinetic of multicomponent substrate removal by activated sludge". Water Res, Vol, 9, 1975, pp.337-342.

17 Luc, F., Pascal, B.A and Georges, D., "Water, wastewater and waste management in brewing industry" .J of Leaner Production, Vol 14, 2006, pp 463-471.

18 Ibrahim M.Abu-Reesh,"Kinetics of anaerobic digestion of labaneh whey in a batch reactor." Biotechnol. Vol. 13,16 2014, pp.1745-1755,

19 Mullai, P., Ngo, H.H and Sabarathianam, P.L., Substrate Removal kinetics of an anaerobic hybrid reactor treating pharmaceutical wastewater. Water Sustainability, Vol. 1,3 (2011), pp. 301-312. 